\title{
THE CONCEPT OF LEGITIMATE ECONOMIC INTEREST
}

\author{
Tymur Loskutov', Sergey Miroshnychenko ${ }^{2}$, Rostyslav Lemekha ${ }^{3}$
}

\begin{abstract}
The purpose of the article is to define the concept of legitimate economic interest. The desired result of scientific research is achieved through the following tasks: the study of theoretical representations in relation to economic interest and legitimate interest, the definition of the concept of legitimate economic interest. The subject of the study is the notion of legitimate economic interest. The methodology of the research is a set of general scientific and special methods of scientific knowledge, which using made possible to study economic interest and legitimate interest and made possible the emergence and disclosure of the concept of legitimate economic interest. As a result of the analysis of scientific views on the notion of economic interest, it is established that scientists do not include legal features, which confirm the legality and legitimacy of economic interest, in its content. The inclusion of legal features in the definition of economic interest causes the definition of the concept of legitimate economic interest. It is concluded that legitimate economic interest is reflected in the legislation and follows from its general meaning. It is a simple economic permit, which is guaranteed, to a certain extent, by state bodies, and is expressed in the economic aspirations and economic actions and relations of a person concerning the fact of using of a particular economic good on the basis of the implementation of economic choice, which result is to change the economic situation of the person. As well as, if necessary, this simple economic permit is expressed in seeking protection from the judicial authorities in order to satisfy their own economy's needs, which do not contradict the public interests, the Constitution and laws of Ukraine, justice, reasonableness, fullness, objectivity, equality, competitiveness and other principles of law. The practical value of scientific research is to reveal the content of an important means of meeting economic needs within the framework of legal regulation. The originality of the research is manifested in the fact that the article attempts to combine signs of economic interest and legitimate interest in defining the concept of legitimate economic interest. This approach provided for the disclosure of the person's economic aspirations in connection with the rules of law. The prospects for further development in the direction of the study of legitimate economic interest are determined, in particular, concerning the fact of its relation with economic law and peculiarities of realization.
\end{abstract}

Key words: economic interest, legitimate interest, legitimate economic interest, economic relations, needs, aspirations, norms.

JEL Classification: K10, K20

\section{Introduction}

Effective development of the economy involves qualitative legislative support for the implementation of economic relations. For the legitimate fulfilment of the needs of economic relations, legal means are provided, the use of which makes it possible to achieve the desired result in the economic sphere. Among the legislative means for the implementation of economic activities, there are generally recognized rights and responsibilities. They are enshrined in legal norms by definition of permissible, obligatory or prohibitive activity for regulation of interaction between the participants of economic relations. However, these legal means do not cover all the aspirations of economic entities to meet their material desires. Therefore, the question arises about the development of other legislative instruments to ensure the implementation of economic relations. One such legal means is legitimate economic interest, which in its nature differs from economic rights and creates additional opportunities in relation to the implementation of different needs in the field of economic activity. In the bundle with this, the theoretical study of legitimate economic interest, in particular, in terms of clarifying its concept, may not be relevant.

\footnotetext{
Corresponding author:

${ }^{1}$ Donetsk Law Institute of the Ministry of Internal Affairs of Ukraine, Ukraine.

E-mail: timloskutov@ukr.net

${ }^{2}$ University of State Fiscal Service of Ukraine, Ukraine.

E-mail: legolas@ua.fm

${ }^{3}$ Danylo Halytsky Lviv National Medical University, Ukraine.

E-mail: roslemekha@gmail.com
} 
Questions about economic interest were investigated by various scholars in the field of economics. At the same time, scientists focused on the study of general aspects of economic interest, economists defined the concept of economic interest without taking into account the law, legislative component.

The methodology of the research is a set of general scientific (analysis, synthesis, induction, deduction, generalization) and special (comparative-economic, comparative-legal, formal-logical, system-structural) methods of scientific knowledge.

The purpose of this article is to define the concept of legitimate economic interest. In order to achieve this goal, the following tasks should be performed: to study theoretical representations regarding economic interest and legitimate interest; to define the notion of legitimate economic interest.

\section{Investigation of the concept of economic interest}

In economic literature, there are widespread views on the definition of the concept of economic interest. K. M. Matusevich writes that economic interests are the personified vital material and spiritual conditions of the existence of people, that is, the conscious economic needs of people. They are the source of motivation for socioeconomic actions of people, the driving force behind social economic reproduction (Matusevich, 2014).

O. E. Babina and Yu. P. Lozova point out that the concept of "economic interest" is a complex category that defines motives and incentives for the actors of market relations, internal and external causes that give rise to economic interests, as well as the purpose of their realization (Babina, Lozova, 2013). O. M. Didenko somewhat develops this definition of economic interest by adding that the motives and incentives of the actors of market relations should be realistic, due to certain property relations and the principle of economic benefits (Didenko, 2013). These points of view on the concept of economic interest look very abstract since scientists use rather general terminology to disclose meaningful features to define this definition. In particular, the following features are unclear in terms of economic interest: spiritual conditions of being of people, the driving force of social economic reproduction, internal and external causes, the purpose of realization, real motives and incentives, etc.

In the theory of economics, in addition to the economic interest of a person, the notion of economic interests of the enterprise, economic interests of the state and national interests in the economic sphere are determined. In particular, in his work, T. V. Sak emphasizes the study of the economic interests of the enterprise, which defines as a system of values that is a consequence of existing needs in the field of economic activity, the achievement of which ensures the achievement of the goals set at each stage of the company's lifecycle (Sak, 2014). The above definition of the economic interests of the enterprise, as well as the previous concepts of economic interest, are too general, without bringing clear, meaningful features. This makes it impossible to separate economic interest from other means of obtaining the necessary result in the course of realization of economic activity of the enterprise.

Ye. Y. Sibertsiyeva distinguishes the category of "economic interests of the state" as an object of protection by the prosecutor in court, the content of which is disclosed through the aggregate of the needs and aspirations of the state represented by bodies of state power, local self-government, enterprises, institutions and organizations in obtaining from participation in economic relations certain values and blessings (Sibirtseva, 2013). Without criticizing the definition of the concept of the economic interests of the state, we are convinced that the issue of economic interest of a person who is not a representative, that is, a part of the state, becomes more relevant. Since the economic interests of an individual are not covered by economic rights and freedoms, they are aimed at satisfying economic needs. Regarding the economic interests of the state, their definition is undoubtedly an important aspect of the economic development of the state. At the same time, in itself the economic interests of the state do not create any optional opportunities for state bodies; the latter pursue economic interests through the exercise of certain powers, which include both rights and obligations.

S. P. Zavgorodnaya investigates national interests in the economic sphere, she proposes to understand the systematic and balanced set of economic needs of the person, society, and the state, which are the basis for the formation of national goals, the achievement of which guarantees the preservation and enhancement of national values, ensuring economic sovereignty and sustainable social and economic development (Zavgorodnaya, 2015). With regard to this definition, our position is similar to the previous concept of the economic interests of the enterprise, that is, the notion of national interests in the economic sphere is disclosed in a rather general form. However, such an approach can be conditioned by the fundamental nature of the very phrase of national interests in the economic sphere.

More meaningful concept of economic interests determines V. L. Smysova, who notes that they are the socio-economic attraction and direction of the subject to meet the needs of economic and social benefits, the content of which is revealed through its economic aspirations and economic interactions (actions, relationships, relations) on the basis of the mechanism of economic choice, which leads to a change in the initial economic/social status of the subject, his economic results, self-development and self-development (Smysova, 2018). 
In general, agreeing with the above concepts of economic interests, we believe that some duplication in relation to the above features is an indication on the one hand to the direction of the subject to meet economic and social needs, and on the other - to economic aspirations. Also, the author unjustifiably blends the signs of economic and social interest, the meaningful features of which must be different.

In addition, all the analysed theoretical views on economic interest have a drawback of ignoring the legal basis, which is a statement of legality and legitimacy of economic interest. In this approach, economic aspirations and interactions may not be in line with legal norms, which may lead to the recognition of economic interests as unlawful.

To take into account in the content of the notion of economic interests the requirements of law and legality consider the concept of legitimate interest. Let's make a critical analysis of definitions of legitimate interest in order to distinguish its essential features and use the latter in the definition of economic interest.

\section{Investigation of the concept of legitimate interest}

T. O. Pikul writes that legitimate interest is legal permission, which, in contrast to subjective law, has the character of legal aspirations. However, legitimate interest can be considered a certain possibility, but in the majority of its social, actual, and not legal (Pikul, 2010). It is difficult for us to agree with the position of the scientist because legitimate interest is always a law (legal) opportunity for the participants of the legal relationship to meet their own needs. Despite the fact that legitimate interests are not explicitly defined in the legislation, they are conditioned by legal obligations, which are directly "formalized" by legal norms. Legal obligations, in particular, legal prohibitions, determine the legal limits of the legitimate interests of the participants in the legal relationship. In addition, the protection of legitimate interests is explicitly provided for by law. Therefore, one cannot but recognize the law (legal) nature of the possibilities, which are the legitimate interests of the participants in the legal relationship.

I. O. Lychenko observes that it is inappropriate to determine the meaning of "legitimate interest" as a permit or aspiration. In the process of formation of legitimate interest, desire or need is a process of awareness, analytical processing and psychological assessment from the person. Therefore, the very desire cannot explain the content of legitimate interest and perceived as an identical concept. The author also notes that legitimate interest is not a permission since the source of its occurrence is not only the will of the state but also the personal aspirations of the subject or the needs of the territorial community that exist objectively related to the very nature of the person, and their protection in some cases it can be manifested in the form of self-defence. That is, the state permit for such interests is not the primary one. They are provided by the state and come into legal significance only in the case of significance for a person and society (Lychenko, 2011). We cannot agree with a scientist because the process of awareness, analytical treatment, and psychological assessment by a person of his desire is not an obstacle to the formulation of the notion of legitimate interest through the term "desire". The use of the latter involves taking into account the psychological attitude of the person to the realization of their own needs by obtaining certain benefits. In addition, legitimate interests are closely linked to normative law. Not prohibited by law, the desire of the participants in the legal relationship is the content of legitimate interests. In other words, it is not forbidden to always allow for aspirations. However, explicit legal permissions do not cover all the legitimate interests of the parties to the legal relationship. Legitimate interests are, first of all, general permits arising from the content of legal acts. Consequently, it is not a mistake to define the concept of "legitimate interest" as a legal decision, which is not directly specified in the law.

The most complete definition of legitimate interest was given by the theoretician A. V. Malko. The latter considers it as reflected in objective law or as a result of its general meaning, and to a certain extent guaranteed by the state of a simple legal permission expressed in the aspirations of the subject to use a particular social benefit, and also in some cases to seek protection to the competent authorities to meet their own needs, which do not contradict the public (Malko, 1999, Malko, 2000). A supporter of this position V. V. Subochev adds that the interests, for which the subject seeks to enjoy a particular social good and, in some cases, seek protection from the competent authorities, should not contradict the rules of law (Subochev, 2009).

In our view, the needs or interests to which the person seeks to be satisfied must comply not only with the norms of law but also with his principles. Therefore, a substantial addition to the signs of legitimate interest are indications contained in the content of the decision of the Constitutional Court of Ukraine, adopted in the case on the constitutional petition of 50 people's deputies of Ukraine regarding the official interpretation of certain provisions of part one of Article 4 of the Civil Procedural Code of Ukraine (a case concerning the protection oflawinterest). In this case, the Constitutional Court has ruled that the needs for satisfaction of which the person's aspiration to use a concrete material and/or immaterial good is directed must be consistent not only with public interests but also with the Constitution and laws of Ukraine, justice, integrity, reasonableness, and other general principles (Decision of the Constitutional Court of Ukraine, 2004).

Thus, the legitimate interest is reflected in the legislation and follows from its general meaning. It is guaranteed to a certain extent by the state bodies and 
is expressed as a simple legal permission in the person's aspirations to use a concrete good and, if necessary, to seek protection from the judiciary in order to meet their own needs, which do not contradict the public interests, the Constitution and laws of Ukraine, justice, reasonableness, completeness, objectivity, equality, competitiveness, and other principles of law.

Taking into account the signs of the legitimate interest concept and the views on the definition of the content of economic interest described above, one can define the notion of legitimate economic interest.

\section{Conclusions}

1. The analysis of theoretical ideas about the concept of economic interest shows that scientists do not include legal features, which confirm the legality and legitimacy of economic interest, in its content. The inclusion of legal features in the definition of economic interest causes the definition of the concept of legitimate economic interest.
2. Legitimate economic interest is reflected in the legislation and follows from its general meaning. It is a simple economic permit, which is guaranteed, to a certain extent, by state bodies, and is expressed in the economic aspirations and economic actions and relations of a person concerning the fact of using of a particular economic good on the basis of the implementation of economic choice, which result is to change the economic situation of the person. As well as, if necessary, this simple economic permit is expressed in seeking protection from the judicial authorities in order to satisfy their own economy's needs, which do not contradict the public interests, the Constitution and laws of Ukraine, justice, reasonableness, fullness, objectivity, equality, competitiveness, and other principles of law.

Prospects for further developments in this direction may be the following: determination of the ratio of legitimate economic interest and economic law; disclosure of peculiarities of legitimate economic interest realization.

\section{References:}

Matusevich, K. M. (2014). Ekonomichnyi interes yak chynnyk i rushiina syla motyvatsii liudskykh dii [Economic interest as a factor and driving force of motivation of human actions]. Scientific Herald of Kherson State University, Series: Economic Sciences, 4, 38-41.

Babina, O. E., Lozova, Yu. P. (2013). Ekonomichni interesy v systemi rynkovykh vidnosyn [Economic interests in the system of market relations]. Water transport, 1, 75-79.

Didenko, O. M. (2013). Teoretychne doslidzhennia naukovo-metodychnykh pidkhodiv do doslidzhennia sutnosti poniattia "ekonomichnyi interes" [Theoretical study of scientific and methodological approaches to the study of the essence of the concept of "economic interest"]. Democratic Governance, vol. 12. Retrieved from: http://nbuv.gov.ua/ UJRN/DeVr_2013_12_33

Sak, T. V. (2014). Ekonomichni interesy maloho pidpryiemnytstva yak obiekt zakhystu [Economic interests of small business as an object of protection]. Investments: Practice and experience, 22, 67-71.

Sibirtseva, E. Yu. (2013). Ekonomichni interesy derzhavy yak obiekt zakhystu prokurorom v administratyvnomu sudochynstvi Ukrainy [Economic interests of the state as an object of protection by the prosecutor in the administrative legal proceedings of Ukraine]. Economics and Law, 1, 66-70.

Zavgorodnaya, S. P. (2015). Natsionalni interesy v ekonomichnii sferi: sutnist ta pobudova yikh iierarkhii [National interests in the economic sphere: the essence and construction of their hierarchy]. Public Administration Aspects, 1-2, 40-47.

Smysova, V.L. (2018). Do pytannia vyznachennia katehorii "ekonomichni interesy" [To the question of determining the category of "economic interests"]. Strategy of economic development of Ukraine, 42, 38-48.

Pikul, T. O. (2010). "Subiektyvne pravo" - "zakonnyi interes": poniattia ta dialektyka spivvidnoshennia ["Subjective right" - "legitimate interest": the concept and the dialectic of the relationship]. Crimean Legal Gazette, 3(10), $151-158$. Lychenko, I. O. (2011). Katehorialnyi analiz poniattia zakonnykh interesiv hromadian u sferi vlasnosti [Categorical analysis of the notion of legitimate interests of citizens in the sphere of property]. Customs business, 1(73), $145-148$. Malko, A. V. (1999). Osnovy teorii zakonnykh interesov [Fundamentals of the theory of legitimate interests]. Journal of Russian Law, 5/6, 66-68.

Malko, A. V. (2000). Subektivnoe pravo i zakonnyy interes [Subjective law and legitimate interest]. Jurisprudence, 3, 31-38.

Subochev, V. V. (2009). Teoriya zakonnykh interesov [Theory of legitimate interests] (Doctor Degree in Law sciences, abstract of thesis, specialty 12.00 .01 - theory and history of law and state, history of exercise on law and state), Tambov: G.R. Derzhavin Tambov State University.

The decision of the Constitutional Court of Ukraine (2004). Shchodo ofitsiinoho tlumachennia okremykh polozhen chastyny pershoi statti 4 Tsyvilnoho protsesualnoho kodeksu Ukrainy (sprava pro okhoroniuvanyi zakonom interes) [concerning the official interpretation of certain provisions of part one of Article 4 of the Civil Procedural Code of Ukraine (case on the protection of law interests)]. Retrieved from: http://zakon.rada.gov.ua/ laws/show/v018p710-04 